Acta vet. scand. $1976,17,354-358$.

From the National Veterinary Institute, Oslo, Norway.

\title{
SEROLOGICAL INVESTIGATIONS OF LEPTOSPIRAL DEOXYRIBONUCLEASES
}

By

Svein Fredrik Mohn and Olav Sandvik

MOHN, SVEIN FREDRIK and OLAV SANDVIK: Serological investigations of leptospiral deoxyribonucleases. Acta vet. scand. 1976, 17, 354-358. - Enzymoserological comparison of a selection of leptospira strains tested with sera from rabbits immunized with unpurified DNase of Leptospira interrogans, serotype canicola, indicates the production of DNase of serologically very similar properties by the serotypes canicola, autumnalis, icterohemorrhagiae and pomona. The DNase produced by serotype hyos was serologically different from the others, while the serotypes grippotyphosa and bataviae did not produce DNases at all. The method used made it possible to differentiate between leptospiral DNase and normally occurring DNases in the serum samples. Neither leptospira DNase nor specific leptospiraDNase-antibodies could be detected in dog sera with high agglutinationlysis titres after natural infection.

leptospiral deoxyribonucleases; serological in vestig ation.

The leptospires have only limited biochemical activity (Bergey's Manual of Determinative Bacteriology 1974), and the possibilities of differentiation between strains and types by biochemical methods are limited. However, in addition to lipolytic enzymes (Ellinghausen \& Sandvik 1965) many strains of leptospires produce deoxyribonucleases (DNases) that can be demonstrated in toluidine blue deoxyribonucleic acid agar (TDA), as used for staphylococcal DNases by Lachica et al. (1971).

As shown for staphylococcal DNases, such systems are suitable for enzymo-serological examinations (Sandvik 1974). This type of investigation is of interest both in order to study the effect of these enzymes on the immune apparatus of the host, and in order to clarify whether DNases produced by different types of leptospires are related serologically. 
The present report deals with enzymo-serological investigations of a selection of leptospira strains (Table 1) tested with sera from rabbits immunized with unpurified DNase-containing Korthof cultures of Leptospira interrogans, serotype canicola. In addition, sera from naturally infected dogs, having shown positive agglutination-lysis titres against one, or more, serotypes and sera having shown negative agglutination-lysis reactions were included.

\section{MATERIALS AND METHODS}

All leptospira cultures used were grown in Korthof's medium with $10 \%$ rabbit serum for $14-21$ days. Cultures used for immunization were grown for four days. Immunization was performed using five intracutaneous injections of leptospira organisms resuspended in saline, to a density corresponding to Mac Farland Tube No. 3, and thoroughly mixed with an equal volume of adjuvant; the first injection with Freunds Complete Adjuvant, the following injections with Incomplete Adjuvant. The rabbits were bled 27 days after the first injection and the sera stored at $-20^{\circ} \mathrm{C}$ until used.

The enzyme activity in the various leptospira cultures was demonstrated on TDA medium adjusted to $\mathrm{pH} 5.6$ with $0.1 \mathrm{M}$ acetate buffer, and the enzymo-serological investigations were carried out by using a DNase inhibition test similar to that used for testing staphylococcal DNases (Sandvik 1974, 1975). By this method, the DNase activity occurs as distinct pink zones in contrast to the otherwise blue medium.

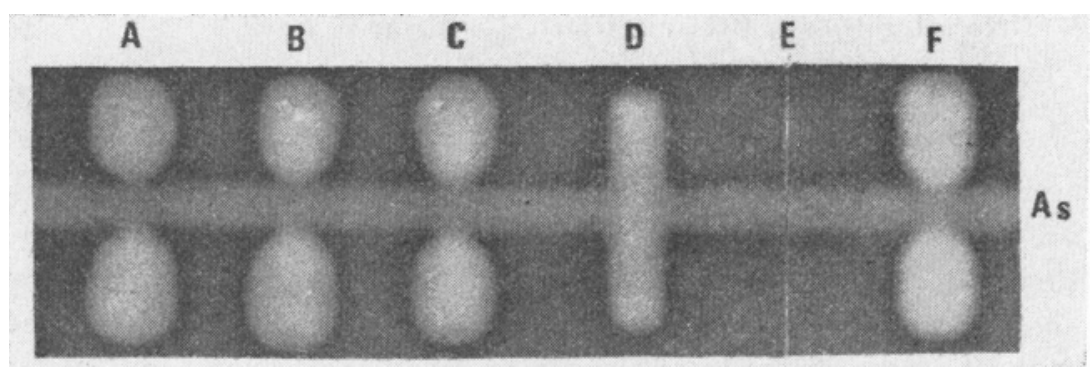

F i g u re 1. Toluidine blue deoxyribonucleic acid agar (TDA) showing DNase zones produced by the serotypes autumnalis (A), australis (B), canicola (C), hyos (D), and icterohemorrhagiae (F), but not by serotype grippotyphosa (E). The DNases produced are inhibited by rabbit-canicola-DNase-antiserum (As) except that of serotype hyos (D). 


\section{RESULTS}

The results, summarized in Table 1 , show DNase activity in all cultures examined except those of serotypes grippotyphosa and bataviae. The DNases were inhibited by the canicola-DNaseantiserum except for the enzyme produced by serotype hyos, which seems to be serologically different from the DNases produced by the other serotypes. Fig. 1 shows typical enzyme zones produced by various leptospira serotypes together with the culture of serotype grippotyphosa showing no enzyme activity.

Table 1. DNase activity of various Leptospira interrogans types and strains, and the inhibition of the enzyme activity by rabbit-canicola-DNase-antiserum.

\begin{tabular}{lllcc}
\hline Culture & Serotype & Strain & $\begin{array}{r}\text { DNase } \\
\text { activity }\end{array}$ & $\begin{array}{r}\text { Inhibition of } \\
\text { DNase activity }\end{array}$ \\
\hline A & autumnalis & autumnalis & $+^{+}$ & $+^{3}$ \\
B & australis & ballico & + & + \\
C & canicola & fly & + & + \\
D & hyos & mitis & + & $\mathbf{0}^{4}$ \\
E & grippotyphosa & mus 266 & -2 & $0^{5}$ \\
F & icterohemorrhagiae & Kautovowicz & + & + \\
G & canicola & NVH & + & + \\
H & pomona & pomona & + & + \\
I & pomona & T 262 & + & + \\
J & bataviae & 17-NVH & - & 0 \\
K & un-inoculated Korthof's & medium & - & 0 \\
\hline
\end{tabular}

1+: DNase activity detected.

2_: DNase activity not detected.

3+: Inhibition of DNase activity.

4_: No inhibition of DNase activity.

50 : Not tested.

The results of the examinations of $11 \mathrm{dog}$ sera for DNase activity and icterohemorrhagiae- and canicola-DNase-antibodies are summarized in Table 2 where the corresponding agglutination-lysis titres for each serum are also indicated. All the sera showed some degree of enzyme activity, but none of the DNasezones were inhibited by the canicola-DNase-antiserum, indicating that the DNases in the dog sera were serologically different from the canicola-DNases. It can also be seen from Table 2 that specific antibodies against leptospira DNases could not be detected in the sera. 
T a b l e 2. DNase activity, inhibition of DNase activity by canicolaDNase-antiserum and content of leptospira-DNase-antibodies of various dog sera.

\begin{tabular}{|c|c|c|c|c|c|c|}
\hline \multirow{3}{*}{$\begin{array}{l}\text { Dog serum } \\
\text { examined }\end{array}$} & \multirow{2}{*}{\multicolumn{2}{|c|}{$\begin{array}{l}\text { Agglutination-lysis } \\
\text { titre }\end{array}$}} & \multirow{3}{*}{$\begin{array}{l}\text { DNase } \\
\text { activity }\end{array}$} & \multirow{3}{*}{$\begin{array}{c}\text { Inhibition of } \\
\text { DNase activity } \\
\text { by canicola-DNase- } \\
\text { antiserum }\end{array}$} & \multicolumn{2}{|c|}{ Antibodies against } \\
\hline & & & & & \multirow{2}{*}{$\begin{array}{l}\text { icteroh.- } \\
\text { DNase }\end{array}$} & \multirow{2}{*}{$\begin{array}{l}\text { canicola- } \\
\text { DNase }\end{array}$} \\
\hline & icteroh. & canicola & & & & \\
\hline 1 & 10,000 & 1,000 & $+^{1}$ & $-^{2}$ & -3 & - \\
\hline 2 & 1,000 & 100 & + & - & - & - \\
\hline 3 & 10,000 & 10 & + & - & - & - \\
\hline 4 & 300 & 3,000 & + & - & - & - \\
\hline 5 & 3,000 & 3,000 & + & - & - & - \\
\hline 6 & 1,000 & 100 & + & - & - & - \\
\hline 7 & 1,000 & 3,000 & + & - & - & - \\
\hline 8 & $<10$ & $<10$ & + & - & - & - \\
\hline 9 & $<10$ & $<10$ & + & - & 一 & 一 \\
\hline 10 & $<10$ & $<10$ & + & - & - & - \\
\hline 11 & $<10$ & $<10$ & + & - & - & - \\
\hline $\begin{array}{l}\text { Rabbit- } \\
\text { canicola- } \\
\text { DNase- } \\
\text { antiserum }\end{array}$ & 300 & 10,000 & $-^{4}$ & & $+^{5}$ & + \\
\hline
\end{tabular}

1+: DNase activity demonstrated.

2_: No inhibition.

3_: Antibodies not demonstrated.

4_: DNase activity not demonstrated.

5+: Antibodies demonstrated.

\section{DISCUSSION}

The examinations demonstrated the production of DNases in most of the cultures examined, except that of the serotypes grippotyphosa and bataviae. The DNases in question seem to have similar serological properties, except that produced by serotype hyos. These preliminary results, however, showing serologically related DNases produced by various leptospira serotypes, support the classification of the majority of the species belonging to the genus Leptospira into serotypes of only one species, Leptospira interrogans (Bergey's Manual 1974).

Neither leptospira DNases nor specific leptospira-DNase-antibodies could be detected in dog sera with high agglutinationlysis titres. These results indicate that the DNase inhibition test 
is probably of little practical value in the serological diagnosis of leptospiroses. However, the test seems to be well suited for further serological studies of leptospira DNases.

\section{REFERENCES}

Bergey's Manual of Determinative Bacteriology, 8th Ed. The Williams and Wilkins Company, Baltimore 1974.

Ellinghausen, H. C., Jr. \& O. Sandvik: Tributyrinase activity of leptospires: fixed and soluble tributyrinase demonstrated by means of an agar diffusion test. Acta path. microbiol. scand. 1965, 65, $259-270$.

Lachica, R. V. F., C. Genigeorgis \& P. D. Hoeprich: Metachromatic agardiffusion methods for detecting staphylococcal nuclease activity. Appl. Microbiol. 1971, 21, 585-587.

Sandvik, $O .:$ The occurrence of antibodies against staphylococcal deoxyribonucleases in blood sera from different species. Acta vet. scand. $1974,15,631-635$.

Sandvik, $O$.: The occurrence of antibodies against staphylococcal deoxyribonucleases in bovine milk. Acta vet. scand. 1975, 16, $140-142$.

\section{SAMMENDRAG}

Serologiske undersøkelser av leptospira-deoxyribonukleaser.

Det er foretatt enzym-serologisk sammenligning av et utvalg av leptospirastammer som ble testet med sera fra kaniner immunisert med urenset DNase fra Leptospira interrogans, serotype canicola. Unders $\varnothing$ kelsene viste at det produseres DNaser med serologisk sett svært like egenskaper av serotypene canicola, autumnalis, icterohemorrhagiae og pomona, mens DNase produsert av serotype hyos var serologisk ubeslektet med de andre og serotype grippotyphosa og bataviae ikke produserte DNaser i det hele tatt.

Den anvendite metode gjorde det mulig å atskille leptospira-DNase fra normalt forekommende DNaser i serumprøvene.

Det kunne ikke påvises hverken leptospira-DNase eller leptospiraDNase-antistoff i hundesera med høye agglutinasjons-lysis-titer som følge av naturlig infeksjon.

(Received August 2, 1976).

Reprints may be requested from Svein Fredrik Mohn, the National Veterinary Institute, Postbox 8156, Oslo Dep., Oslo 1, Norway. 